\title{
Front Matter: Volume 9944
}

, "Front Matter: Volume 9944," Proc. SPIE 9944, Organic Sensors and Bioelectronics IX, 994401 (16 December 2016); doi: 10.1117/12.2262997

SPIE Event: SPIE Organic Photonics + Electronics, 2016, San Diego, California, SPIE. United States 


\title{
PROCEEDINGS OF SPIE
}

\section{Organic Sensors and Bioelectronics IX}

\author{
loannis Kymissis \\ Ruth Shinar \\ Luisa Torsi \\ Editors
}

28-29 August 2016

San Diego, California, United States

Sponsored and Published by

SPIE 
The papers included in this volume were part of the technical conference cited on the cover and title page. Papers were selected and subject to review by the editors and conference program committee. Some conference presentations may not be available for publication. The papers published in these proceedings reflect the work and thoughts of the authors and are published herein as submitted. The publisher is not responsible for the validity of the information or for any outcomes resulting from reliance thereon.

Please use the following format to cite material from these proceedings:

Author(s), "Title of Paper," in Organic Sensors and Bioelectronics IX, edited by loannis Kymissis, Ruth Shinar, Luisa Torsi, Proceedings of SPIE Vol. 9944 (SPIE, Bellingham, WA, 2016) Six Digit Article CID Number.

ISSN: 0277-786X

ISSN: 1996-756X (electronic)

ISBN: 9781510602809 (electronic)

ISBN: 9781510602793

Published by

SPIE

P.O. Box 10, Bellingham, Washington 98227-0010 USA

Telephone +13606763290 (Pacific Time) · Fax +13606471445

SPIE.org

Copyright @ 2016 , Society of Photo-Optical Instrumentation Engineers.

Copying of material in this book for internal or personal use, or for the internal or personal use of specific clients, beyond the fair use provisions granted by the U.S. Copyright Law is authorized by SPIE subject to payment of copying fees. The Transactional Reporting Service base fee for this volume is $\$ 18.00$ per article (or portion thereof), which should be paid directly to the Copyright Clearance Center (CCC), 222 Rosewood Drive, Danvers, MA 01923. Payment may also be made electronically through CCC Online at copyright.com. Other copying for republication, resale, advertising or promotion, or any form of systematic or multiple reproduction of any material in this book is prohibited except with permission in writing from the publisher. The CCC fee code is 0277-786X/16/\$18.00.

Printed in the United States of America.

Publication of record for individual papers is online in the SPIE Digital Library.

\section{SPIE. DIGITAL \\ SPIEDigitallibrary.org}

Paper Numbering: Proceedings of SPIE follow an e-First publication model. A unique citation identifier (CID) number is assigned to each article at the time of publication. Utilization of CIDs allows articles to be fully citable as soon as they are published online, and connects the same identifier to all online and print versions of the publication. SPIE uses a six-digit CID article numbering system structured as follows:

- The first four digits correspond to the SPIE volume number.

- The last two digits indicate publication order within the volume using a Base 36 numbering system employing both numerals and letters. These two-number sets start with 00, 01, 02, 03, 04, 05, 06, 07, 08, 09, OA, OB ... OZ, followed by 10-1Z, 20-2Z, etc. The CID Number appears on each page of the manuscript. 


\title{
Contents
}

\author{
$\checkmark \quad$ Authors \\ vii Conference Committee
}

ORGANIC SENSORS AND BIOELECTRONICS I

994404 Performance assessment of polymer based electrodes for in vitro electrophysiological sensing: the role of the electrode impedance [9944-4]

ORGANIC SENSORS AND BIOELECTRONICS II

994406 Photoconverters with organic semiconductors and photosynthetic bacteria: positioning the bacterial Reaction Center in nanostructures (Invited Paper) [9944-5]

\section{ORGANIC SENSORS AND BIOELECTRONICS III}

$994409 \quad$ Ultra-efficient all-printed organic photodetectors [9944-8]

\section{ORGANIC SENSORS AND BIOELECTRONICS VI}

9944 ON Organic field effect transistor with ultra high amplification (Invited Paper) [9944-21]

9944 OP Whole organic electronic synapses for dopamine detection (Invited Paper) [9944-23]

\section{ORGANIC SENSORS AND BIOELECTRONICS VII}

9944 OR Perovskite based photosensor for electrochemical studies [9944-25]

\section{POSTER SESSION}

9944 OT Solution processed integrated pixel element for an imaging device [9944-27]

$9944 \mathrm{OV}$ Effect of film morphology on oxygen and water interaction with copper phthalocyanine [9944-29]

9944 OY Low-cost scalable quartz crystal microbalance array for environmental sensing [9944-33] 
Proc. of SPIE Vol. $9944994401-4$

Downloaded From: https://www.spiedigitallibrary.org/conference-proceedings-of-spie on 26 Apr 2023 Terms of Use: https://www.spiedigitallibrary.org/terms-of-use 


\section{Authors}

Numbers in the index correspond to the last two digits of the six-digit citation identifier (CID) article numbering system used in Proceedings of SPIE. The first four digits reflect the volume number. Base 36 numbering is employed for the last two digits and indicates the order of articles within the volume. Numbers start with 00, 01, 02, 03, 04, 05, 06, 07, 08, 09, 0A, 0B...0Z, followed by 10-1Z, 20-2Z, etc.

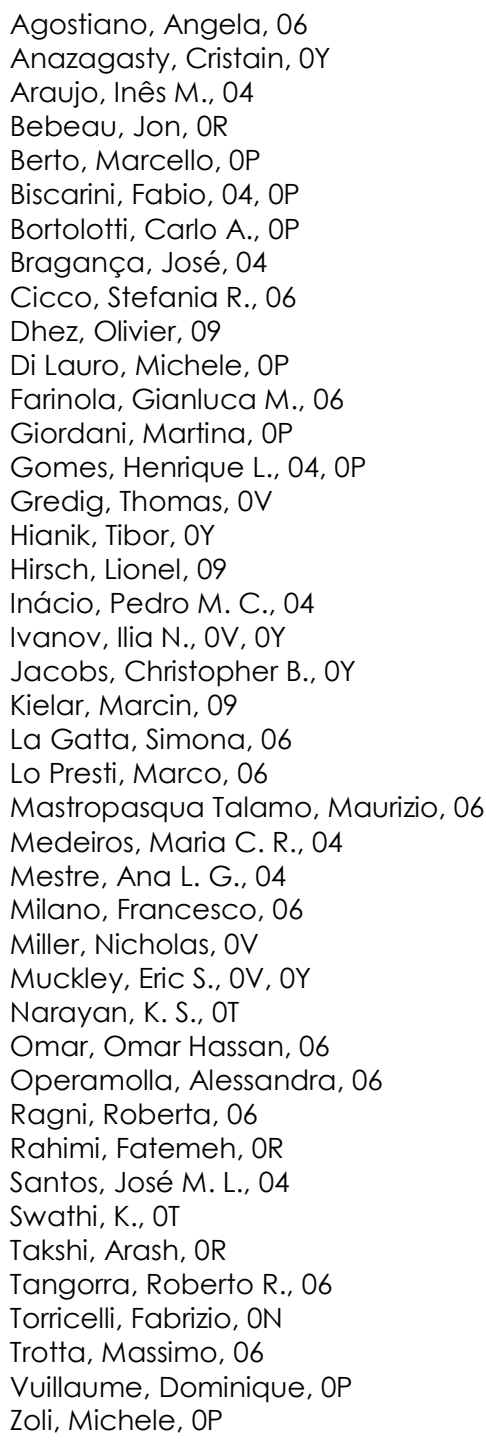


Proc. of SPIE Vol. $9944994401-6$

Downloaded From: https://www.spiedigitallibrary.org/conference-proceedings-of-spie on 26 Apr 2023 Terms of Use: https://www.spiedigitallibrary.org/terms-of-use 


\section{Conference Committee}

Symposium Chairs

Zakya H. Kafafi, Lehigh University (United States)

Luisa Torsi, Università degli Studi di Bari Aldo Moro (Italy)

Conference Chairs

Ioannis Kymissis, Columbia University (United States)

Ruth Shinar, lowa State University (United States)

Luisa Torsi, Università degli Studi di Bari (Italy)

Conference Program Committee

Magnus Berggren, Linköping University (Sweden)

Annalisa Bonfiglio, Università degli Studi di Cagliari (Italy)

Fabio Cicoira, Ecole Polytechnique de Montréal (Canada)

Alon Gorodetsky, University of California, Irvine (United States)

Emil J. W. List-Kratochvil, Technische Universität Graz (Austria)

George G. Malliaras, Ecole Nationale Supérieure des Mines de Saint-

Étienne (France)

Paul Meredith, The University of Queensland (Australia)

Róisín M. Owens, Ecole Nationale Supérieure des Mines de Saint-

Étienne (France)

Manijeh Razeghi, Northwestern University (United States)

Ifor D. W. Samuel, University of St. Andrews (United Kingdom)

Franky So, North Carolina State University (United States)

\section{Session Chairs}

1 Organic Sensors and Bioelectronics I

Paul L. Burn, The University of Queensland (Australia)

2 Organic Sensors and Bioelectronics II

Emil J. W. List-Kratochvil, Humboldt-Universität zu Berlin (Germany)

3 Organic Sensors and Bioelectronics III

Joseph Shinar, lowa State University of Science and Technology

(United States)

4 Keynote Session: Joint Session with Conferences 9930 and 9944

Ruth Shinar, lowa State University of Science and Technology

(United States)

Hooman Mohseni, Northwestern University (United States) 
5 Organic Sensors and Bioelectronics IV

Paul Meredith, The University of Queensland (Australia)

6 Organic Sensors and Bioelectronics $V$

John C. de Mello, Imperial College London (United Kingdom)

7 Organic Sensors and Bioelectronics VI

Jonathan Rivnay, PARC, A Xerox Company (United States)

8 Organic Sensors and Bioelectronics VII

Paul Meredith, The University of Queensland (Australia) 